\title{
MACHINABILITY ESTIMATION BY DRILLING MONITORING
}

\author{
Hernán A. González-Rojas ${ }^{1}$, Amelia Nápoles-Alberro², Antonio J. Sánchez-Egea 3,4 \\ 1Department of Mechanical Engineering (EPSEVG), GAECE group, Universitat Politécnica de Catalunya, Av. de VIctor Balaguer \\ 1, Vilanova i la Geltrú. 08800, Barcelona, Spain, +34-938967795, hernan.gonzalez@upc.edu \\ 2Department of Mechanical Engineering (EPSEVG), TECNOFAB group, Universitat Politécnica de Catalunya, Av. de VIctor \\ Balaguer 1, Vilanova i la Geltrú. 08800, Barcelona, Spain. \\ ${ }^{3}$ Department of Mechanical and Metallurgical Engineering, Pontificia Universidad Católica de Chile, Av. Vicuña Mackenna 4860, \\ 7820436 Region Metropolitana, Chile. \\ ${ }^{4}$ Department of Mechanical Engineering, Aeronautics Advanced Manufacturing Center (CFAA), Faculty of Engineering of Bilbao, \\ Alameda de Urquijo s/n, 48013 Bilbao, Spain.

\section{Received: 3/May/2018--Reviewing: 16/May/2018--Accepted: 3/Jul/2018--DOl: http://dx.doi.org/10.6036/8821}

\section{ESTIMACIÓN DE LA MAQUINABILIDAD MEDIANTE MONITORIZACIÓN DEL TALADRADO}

\section{ABSTRACT:}

This article describes the development of a methodology to measure the specific cutting energy (SCE) in drilling. The SCE allows to characterize the machining process, thus obtaining a technologic approach to plan the technologic road map of the chip removal process. The main frame of this machine consists of a pedestal drill, instrumented with a meter, a motor that controls the spindle feed rate, safety elements such as limit switches and an active power meter coupled to the drill motor. The mechanical power is calculated indirectly through the active power. To this end, it must have a previous calibration with a dynamometer torque cell to record the output curve and, subsequently, display the relationship between the mechanical power and the active electrical power. To validate the capability of this method, SCE of three different materials are evaluated: 7075-T6 aluminium, C45E steels and 34CrNiMo6. Accordingly, it has been verified that the estimated SCE values correspond to those described by the literature. The influence of several parameters, like the cutting speed and the feed rate, on the SCE let us estimate the sensitivity of this method. Finally, this works shows that the SCE in steel increases with the increase of the feed rate, whereas in aluminium the behaviour is the opposite, the SCE decreases as the feed rate increases.

Keywords: Specific cutting energy, material removal rate, cutting power, feed rate, drilling.

\section{RESUMEN:}

Este artículo describe el desarrollo de un método para evaluar la Energía Específica de Corte (EEC) en el taladrado. Este parámetro permite caracterizar el proceso de mecanizado, obteniendo con ello un modelo tecnológico general que permite realizar la planificación del proceso de arranque de viruta. El cuerpo principal de la máquina está formado por un taladro de pedestal, instrumentalizado con: un motor que controla la velocidad de avance del husillo, los elementos de seguridad para los finales de carrera y un medidor de potencia activa acoplado al motor del taladro. La potencia mecánica se obtiene indirectamente a través de la potencia activa, realización una calibración previa con un dinamómetro de par, de la que se obtiene la curva que relaciona la potencia mecánica con la potencia activa. Para demostrar el correcto funcionamiento del método se evalúa la EEC de tres materiales, un aluminio 7075-T6 y los aceros C45E y 34CrNiMo6. Se ha podido comprobar que los valores estimados de energía corresponden a los descritos en la literatura. Un estudio de la dependencia que tiene la EEC de los parámetros velocidad de corte y velocidad de avance, permite observar la sensibilidad del método. Finalmente, este trabajo muestra que la EEC en los aceros aumenta a medida que aumenta la velocidad de avance, en cambio en el aluminio el comportamiento es inverso, la EEC disminuye a medida que la velocidad de avance aumenta.

Palabras clave: Energía específica de corte, tasa de material removido, potencia de corte, velocidad de avance, taladrado. 


\begin{tabular}{|l|l|r|}
\hline Ingeniería e Industria & MACHINABILITY ESTIMATION BY DRILLING MONITORING & $\begin{array}{r}\text { ELECTRICAL AND } \\
\text { MECHANICAL } \\
\text { ENGINEERING } \\
\text { RESEARCH ARTICLE }\end{array} \mid \begin{array}{r}\text { Machine, tool, } \\
\text { accessories }\end{array}$ \\
\hline
\end{tabular}

\section{1.- INTRODUCTION}

Due to the increase in the price of energy, the efficiency of the machining processes has gradually become the center of attention, both in the academic as well as industrial areas. Above all, it is considered that the economic impact of the machining processes is approximately $15 \%$ in the manufacturing products [1]. It can be seen that the machining sectors relating to the geometry of the tool and the Specific Cutting Energy (SCE) have been making great progress since 1950. Several studies have been carried out for machining with conventional cutting at high speed. The material removal rate is one of the important parameters in the processes of chip removal since all the cutting conditions are defined in this parameter. SCE and machining forces [2] are a usual parameter to study. In a similar way, the volume of the material removed is also an objective of study for conventional materials and aeronautical alloys, which are currently booming [3]. These materials are difficult to machine and lack of information on machining parameters can delay their applications to the aerospace and automotive industry.

The SCE can be considered as the relationship between the cutting power and the material removal rate, similar to the relation between the cutting energy and the volume of chip removed [4]. This definition makes it possible to create general technological models which allow accurate planning of the chip removal process. The classical models of forces indicated that the specific cutting force can not be modeled by using a single analytical function of low-level, mainly characterized due to the presence of size-effect [5]. The study of the SCE has an important empirical component as shown in the following works. Rodrigues et al. [6] evaluates the SCE in a high speed front milling, as a function of the cutting speed and the geometry of the tool. The forces in this experiment are measured with a dynamometer table and the volume of material removed is obtained by measuring the mass difference of material before and after machining. In addition, SCE can be considered as an adequate parameter to study high speed milling (HSC). This represents the cutting phenomenon very well, since it is normalized and more sensitive to the low depth of cut which is the characteristic of HSC operations. Jun et al. [7] presents a model for the specific energy consumption of the manufacturing processes, with the objective of obtaining the energy footprint for a machining process and plan the processes that required to define the cutting conditions. The specific cutting energy consumption is defined as the quotient between the integral of the active power per unit time divided by the unit volume of material removed. Wu et al. [8] studied the SCE in a micro-machining by turning, where the chip formation is characterized by a negative rake angle, that produces a non-linear increase in the SCE. This parameter is evaluated as the quotient between the cutting force and cutting area, defined as the product of undeformed chip thickness and the cutting width. In general, in all the aforementioned works, the SCE is obtained as a quotient between the shear force measured experimentally and the section of chip removed.

Normally, the main objective is usually to optimize the energy consumed in the process, due to the impact that this consumption has on the environment [9]. Another way of estimating the SCE is that explained by Sánchez et al. [10], in which they studied the machining in turning process assisted by current pulses. In this work they used the SCE to compare the assisted machining process with respect to conventional machining, and evaluated that the sensitivity shown by the SCE in the characterization of the chip removal process is very useful to characterize both processes. Similarly, Hameed et al. [11] compared conventional drilling with drilling assisted with current pulses, and verified that the assisted process consumed less energy than conventional, which also made the SCE to decrease and therefore the material was easier to machine.

In all the aforementioned works, the evaluation of the SCE required time of experimentation and the used of equipment, with its corresponding cost and uncertainty, that is not always the scope of the research centers and the industry. The objective of this work is to develop a machine and a methodology that allows to estimate quickly the SCE, permitting any workshop to define the cutting conditions appropriate to the machining process being carried out and the materials to be processed. Therefore, in this work we evaluate the SCE of three different materials, an aluminum and two steels, with the purpose of validating above mentioned instrumentation of the process. The dependence of the SCE on the cutting speed and the feed rate is also studied to evaluate the sensitivity of the machine and the machinability of the different materials. Finally, it should be noted that the estimation method of SCE can be applied to any other chip removal process, such as machining in which there is a natural or self-excited vibration [12].

\begin{tabular}{|c|c|c|c|}
\hline & $\begin{array}{c}\text { Publicaciones DYNA SL - c) Mazarredo no69 - 40 - 48009-BILBAO (SPAIN) } \\
\text { Tel +34 } 944237566 \text { - www.revistadyna.com - email: dyna@revistadyna.com }\end{array}$ & Pag. 2 / 84 \\
\hline
\end{tabular}




\begin{tabular}{|c|c|c|}
\hline $\begin{array}{l}\text { Ingenieria e Industria } \\
\text { (S) }\end{array}$ & MACHINABILITY ESTIMATION BY DRILLING MONITORING & $\begin{array}{r}\text { ELECTRICAL AND } \\
\text { MECHANICAL } \\
\text { ENGINEERING }\end{array}$ \\
\hline RESEARCH ARTICLE & Hernán A. González Rojas, Amelia Nápoles Alberro, Antonio J. Sánchez Egea & $\begin{array}{r}\text { Machine, tool, } \\
\text { accessories }\end{array}$ \\
\hline
\end{tabular}

\section{2.- MATERIALS AND METHODOLOGY}

The tested materials are 7075-T6 aluminum, C45E carbon steel (standard UNE F1140) and 34CrNiMo6 steel (norm UNE F1272). The specimens used were a cylindrical bar of $30 \mathrm{~mm}$ diameter and $20 \mathrm{~mm}$ length, which are drilled with different diameters and depth between $10 \mathrm{~mm}$ and $15 \mathrm{~mm}$, as shown in Fig. 1. The tools used in the experiments are conventional drills of high speed steel HSS DIN 338. Several diameters were used: 3.0; 4.5 and 5.5 mm, with tip angle of $118^{\circ}$ and helix angle of $25^{\circ}$. The holes were made by 3 drills each of the aforementioned diameters.

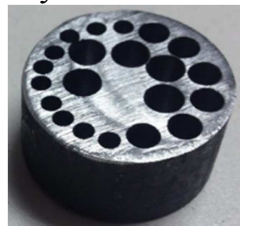

Fig. 1. C45E carbon steel drilled test tube for measuring machinability using different drills.

To estimate the SCE, the mechanical cutting power Pm was measured experimentally and material removal rate Qc was calculated. Then, the evaluation process and the equipment used were described. The main body of the machine is a conventional drilling and the movement of spindle is controlled by the pulley which is replaced the typical crank, see Fig. 2a. The pulley is driven by the belt which is moved by the DC motor. This motor has a worm derive reduction and is controlled by an adjustable voltage of $5 \mathrm{~V}$ to $15 \mathrm{~V}$ and $2 \mathrm{~A}$, which allows to define different feed velocities of the spindle and therefore of the drill, see Fig.2b.

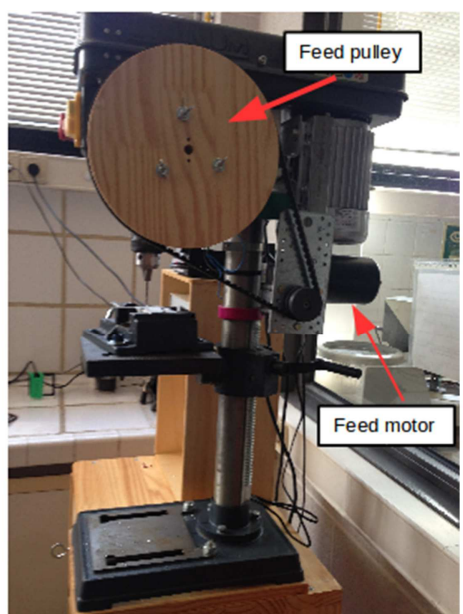

a)

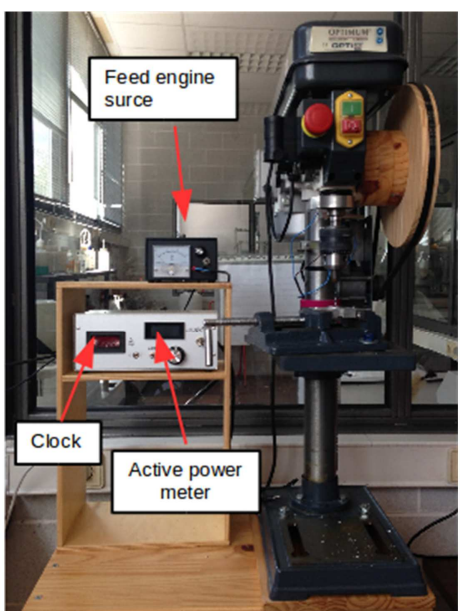

b)

Fig. 2. Instrumentation of the drill and complementary measuring equipment.

The feed rate of drill was calculated by determining the distance of drill goes through the material and the time it takes to make hole. For this, an optical device is used that controls the switch on and off to measure the time during movement. The distance travelled is measured by a metal plate of $5.5 \mathrm{~mm}$ in length was placed in front of the optical sensor. The maximum feed is limited by two limit switches that can be adjusted to define the drilling length. Knowing the drill diameter $(\mathrm{Db})$, the feed rate $(\mathrm{Va})$ and the tip angle of drill $(\alpha)$, the material removal rate can be estimated by the equation (1):

$Q c=\frac{\pi \cdot D b^{2} \cdot V a}{4 \cdot \sin (\alpha / 2)}$

The mechanical power consumed during the drilling was evaluated indirectly through the previous measurement of the active power consumed by the motor of the drill $\mathrm{Pa}$. The device that measures the active power is built with an analogue chip, multiplier of 4 quadrants AD633, which delivers instantly the product of the motor supply voltage and the current consumed. The electrical characteristics are: maximum voltage of $350 \mathrm{~V}$, maximum current of $2.5 \mathrm{~A}$ and maximum output voltage analogue of $5 \mathrm{~V}$ proportional to the active power consumed by the motor. The output signal is subsequently digitized with a digital analogue converter. On the other hand, the mechanical power delivered by the

\begin{tabular}{|c|c|c|}
\hline & $\begin{array}{l}\text { Publicaciones DYNA SL -- c) Mazarredo n69 - } 4^{\circ}-\text { - 48009-BILBAO (SPAIN) } \\
\text { Tel +34 } 944237566 \text { - www.revistadyna.com - email: dyna@revistadyna.com }\end{array}$ & Pag. 3 / 8 \\
\hline
\end{tabular}




\begin{tabular}{|c|c|c|}
\hline $\begin{array}{l}\text { Ingeniería e Industria } \\
\text { S }\end{array}$ & MACHINABILITY ESTIMATION BY DRILLING MONITORING & $\begin{array}{r}\text { ELECTRICAL AND } \\
\text { MECHANICAL } \\
\text { ENGINEERING }\end{array}$ \\
\hline RESEARCH ARTICLE & Hernán A. González Rojas, Amelia Nápoles Alberro, Antonio J. Sánchez Egea & $\begin{array}{l}\text { Machine, tool, } \\
\text { accessories }\end{array}$ \\
\hline
\end{tabular}

motor multiplied by the mechanical efficiency of the drill allows to obtain the cutting power. The mechanical efficiency is not known and also the relationship between active power and mechanical power is unknown. To obtain this relationship, an experiment has been carried out in which the mechanical load is imposed on the drill. This load is applied by a dynamometric brake developed specifically for this application [13]. The experiments were carried out for a spindle speed of $584 \mathrm{~min}-1$, this being any speed, and equally valid to verify the method developed in this work. With the values of mechanical power due to the load and the measurements of the active power consumed by the spindle, a linear regression was performed to obtain a relation for both powers, as shown in Fig. 3. This function will be applied to the measurements of active power, subsequently obtained in drilling tests.

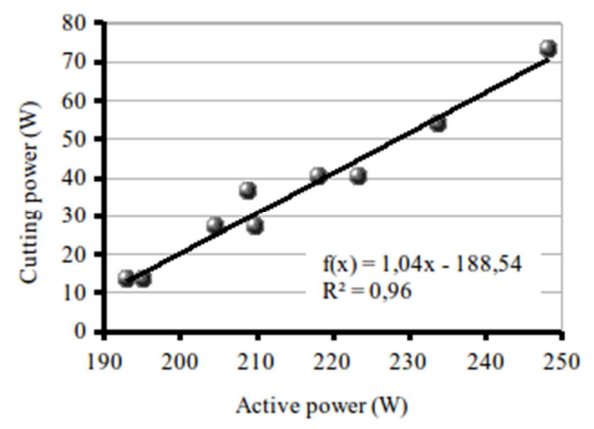

Fig. 3. Regression between mechanical power and active power during drilling at different loads.

Drilling experiments were carried out with the cutting conditions summarized in Table 1, in which different drill diameters and feed rates were used. All the experiments were repeated five times in order to obtain statistically significant results. With each of the combinations of $\mathrm{Va}$ and $\mathrm{Db}, 5$ tests were carried out, which were subjected to Anderson Darling normality test to define the confidence intervals of the sample.

Table 1. Materials studied and cutting conditions used during drilling.

\begin{tabular}{cccc}
\hline Material & $\begin{array}{c}\mathbf{D b} \\
(\mathbf{m m})\end{array}$ & $\begin{array}{c}\mathbf{V} \boldsymbol{c} \\
(\mathbf{m} / \mathbf{m i n})\end{array}$ & $\begin{array}{c}\mathbf{V a} \\
(\mathbf{m m} / \mathbf{s})\end{array}$ \\
\hline & 3 & 5,5 & 0,6 \\
7075-T6 & 3 & 5,5 & 1,4 \\
aluminum & 3 & 5,5 & 2 \\
& 4,5 & 8,2 & 0,6 \\
& 4,5 & 8,2 & 1,4 \\
& 5,5 & 10 & 0,7 \\
& 5,5 & 10 & 1,5 \\
& 5,5 & 10 & 2 \\
\hline C45E carbon & 3 & 5,5 & 0,6 \\
steel & 3 & 5,5 & 1 \\
& 4,5 & 8,2 & 0,6 \\
& 4,5 & 8,2 & 0,9 \\
& 5,5 & 10 & 0,7 \\
34CrNiMo6 & 5,5 & 10 & 0,9 \\
stainless steel & 3 & 5,5 & 0,6 \\
& 3 & 5,5 & 0,7 \\
& 4,5 & 8,2 & 0,6 \\
& 5,5 & 10 & 0,7 \\
\hline
\end{tabular}

To analyze the data of active power, a software was developed in Lazarus Pascal language, in which a section of signal can be selected graphically to obtain its average value in that interval. Fig. 4 shows the digital signal of active power without load and active cutting power. Then, according to the linear regression, the mechanical power was calculated for each stage and finally, the cutting power was obtained as the difference between the mechanical power in the drilling minus the mechanical power without load.

\begin{tabular}{|c|c|c|}
\hline & $\begin{array}{l}\text { Publicaciones DYNA SL -- c) Mazarredo n'69 - } 4^{\circ} \text { - } 48009 \text {-BILBAO (SPAIN) } \\
\text { Tel +34 } 944237566 \text { - www.revistadyna.com - email: dyna@revistadyna.com }\end{array}$ & Pag. $4 / 8$ \\
\hline
\end{tabular}



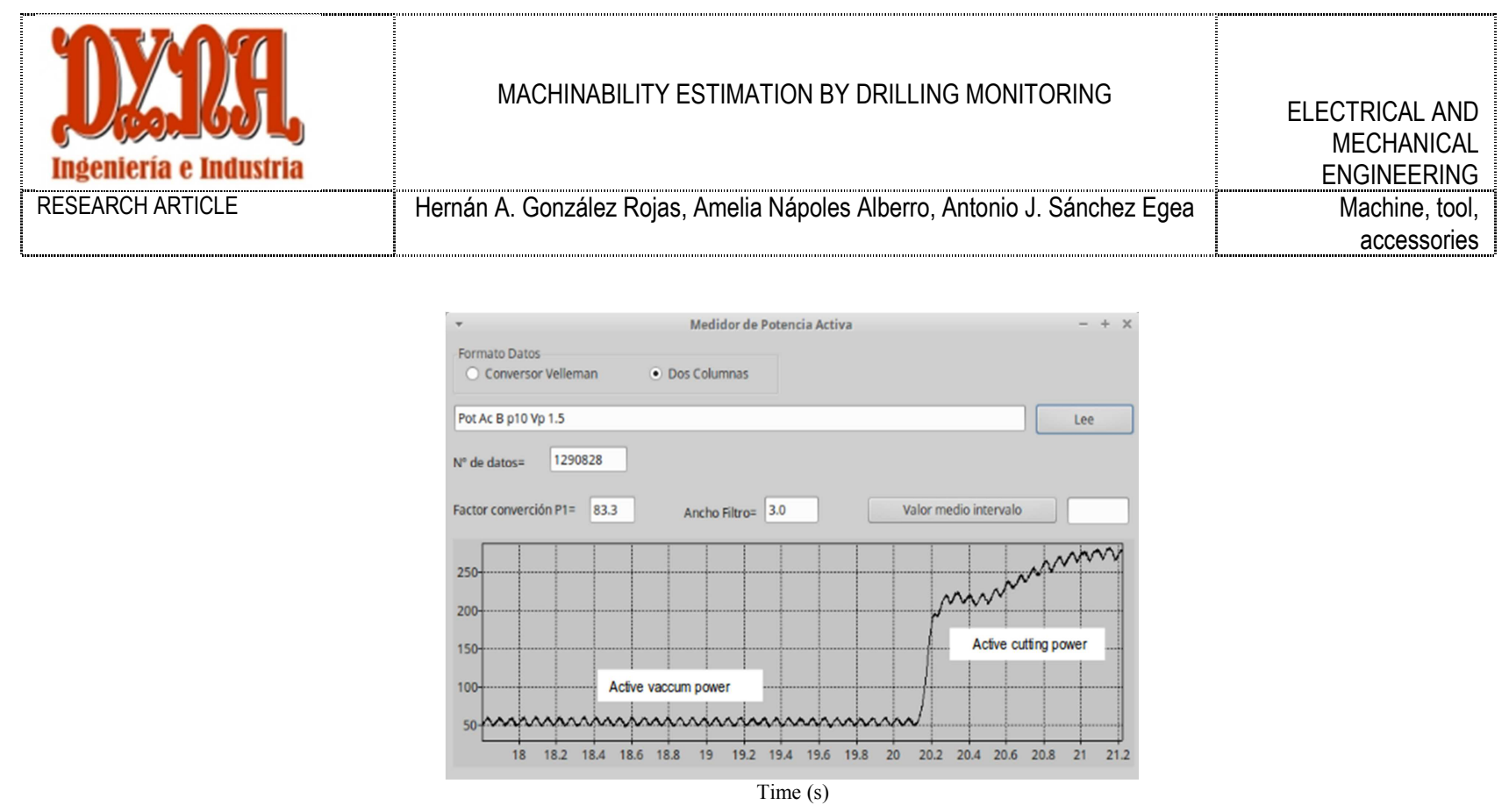

Fig. 4. Software developed in Pascal to determine the active power in vacuum and the cutting power.

\section{3.- RESULTS}

In Fig. 4. the readings of active power $(\mathrm{Pa})$ are shown during drilling. Here, it is observed that the active power behavior is characterized by two stages. In the first stage, the $\mathrm{Pa}$ is constant and corresponded to the power consumed by the drill without load. While in the second stage, it can be seen a non-linear increase in the Pa due to the process of chip removal. In this last stage there is a rapid increase of the Pa during the first seconds, then the growth rate decreases until pseudo-transition stage is reached. The continuous increase that occurs in the last seconds is probably due to an energy dissipation due to the increases the friction chip-cavity and tool-cavity. The active power used to determine the SCE is the average value in a range, which starts at $3 \mathrm{~s}$ from the beginning of the cutting and ends when the last data of power is recorded.

In Fig. 5, the specific cutting energy is represented as a function of the material and the drill diameter. In these experiments, the spindle speed of the drill is constant and equal to $584 \mathrm{~min}^{-1}$. All experiments have shown a normal behavior in the Anderson-Darling test defined by a p-value greater than or equal to 0.27 . Therefore, it was decided to use a t-Student type distribution model to characterize the behavior of the SCE. In this model, the data is characterized by the mean and its confidence intervals. As it can be seen in Fig. 5, the confidence intervals are smaller and allow the separation between groups, in other words, the drilling with these drills generates statistical differences in the behavior of the SCE.

As expected, the SCE of the 7075-T6 aluminium is smaller than the SCE of the studied steels, and in turn the SCE of the C45E carbon steel is smaller than the SCE of the alloy $34 \mathrm{CrNiMo6}$ stainless steel. On the other hand, the behavior of aluminum shows an increase in the SCE when using a drill of $4.5 \mathrm{~mm}$ diameter indicating a non-linear behavior. The data obtained from the SCE for the steel are within the range defined by Kalpakjian [14], while the values of the SCE of the 7075-T6 aluminium are above the range defined by this author. This may be due to the fact that the 7075-T6 aluminium alloy used in this work has greater mechanical performance, since Kalpakjian did not specify the type of aluminum used in his experiments. A recent study showed that the SCE for S45C steel was between 3.8 and $5.1 \mathrm{~J} / \mathrm{mm}^{3}$ [7]. This material is equivalent to the C45E used in this study and it can be seen in Fig.5, the SCE is within the mentioned range. The behavior shown by both steels is similar and in both cases it can be seen that the SCE depends on non-linear form of the volume of chip removed. An optimization exists that corresponds to the volume of chip associated with the minimization of SCE. Similarly, in the previous article it was shown that the SCE for an aluminum alloy was between 2.2 and $3.8 \mathrm{~J} / \mathrm{mm}^{3}$ [7]. While, the aluminum 7075-T6 alloy is within the described range, as shown in Fig.5. Another recent study shows that steel S235 in a process of turning, has CEE in the range between 4.2 and $5.8 \mathrm{~J}$ $/ \mathrm{mm}^{3}$ [15], which indicates that, a higher the feed rate and depth of cut, the smaller is SCE. However, it states that the cutting speed does not influence the SCE for the indicated range.

\begin{tabular}{|c|c|c|}
\hline & $\begin{array}{l}\text { Publicaciones DYNA SL -- c) Mazarredo n69 - } 4^{\circ} \text {-- 48009-BILBAO (SPAIN) } \\
\text { Tel +34 } 944237566 \text { - www.revistadyna.com - email: dyna@revistadyna.com }\end{array}$ & Pag. 5 / 8 \\
\hline
\end{tabular}



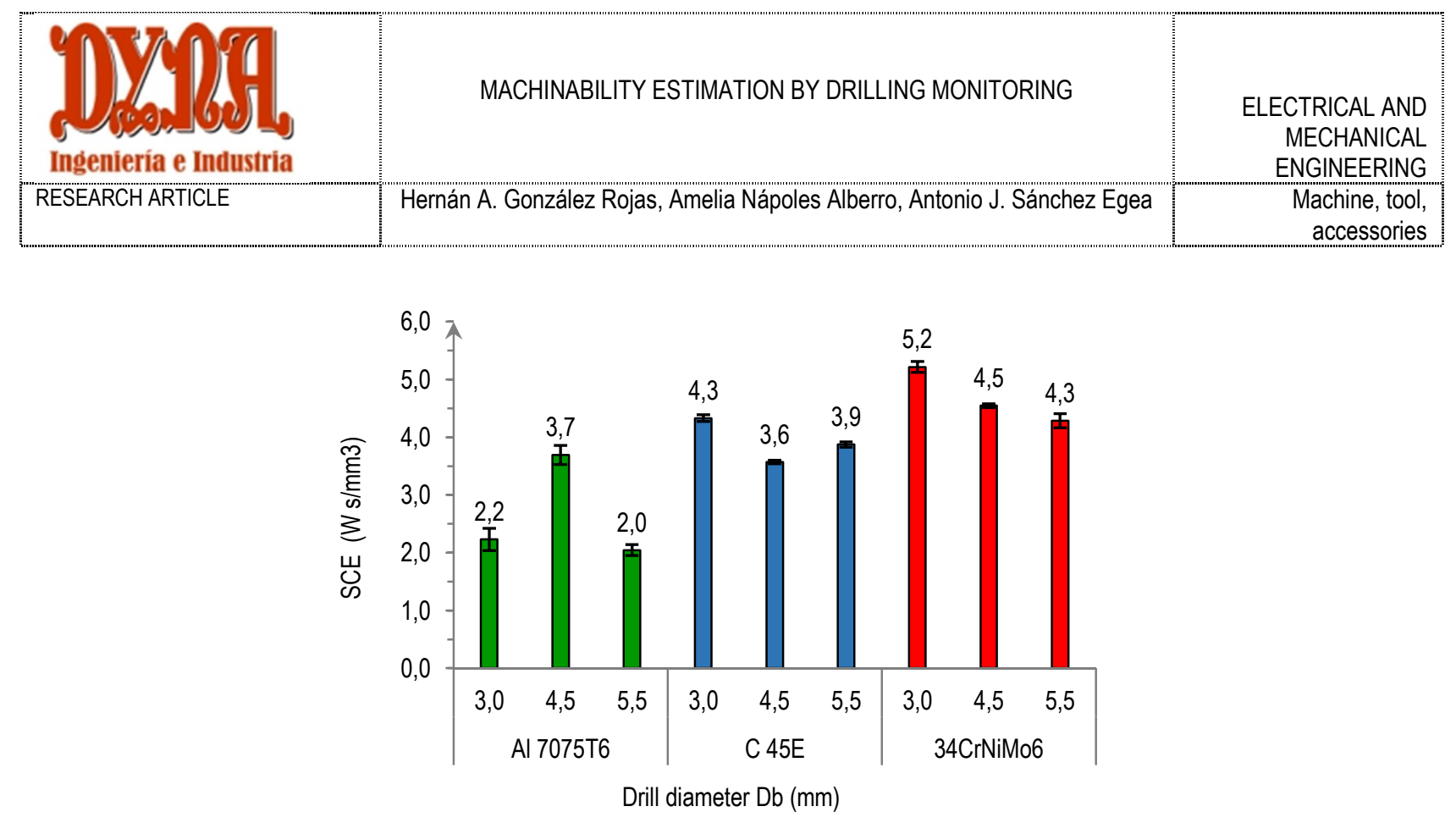

Fig.5 SCE depending on the material and diameter of the bit for a feed rate of $0.6 \mathrm{~mm} / \mathrm{s}$.

The relationship between the SCE and the drill diameter are shown in Fig. 5. If the drill diameter increases, the average cutting speed at the edge increases. The Fig. 5 shows that as the cutting speed increases in the steels, the SCE tends to decrease as described during drilling [11] and milling [6]. Additionally, in Fig.6a and Fig.6b the specific cutting energy is represented as a function of the feed velocity Va. Specifically, in Fig.6a the cutting speed is $5.5 \mathrm{~m} / \mathrm{min}$, lower than in Fig.6b which is $10 \mathrm{~m} / \mathrm{min}$. These two figures show that the behavior of the SCE depends on the cutting speed.

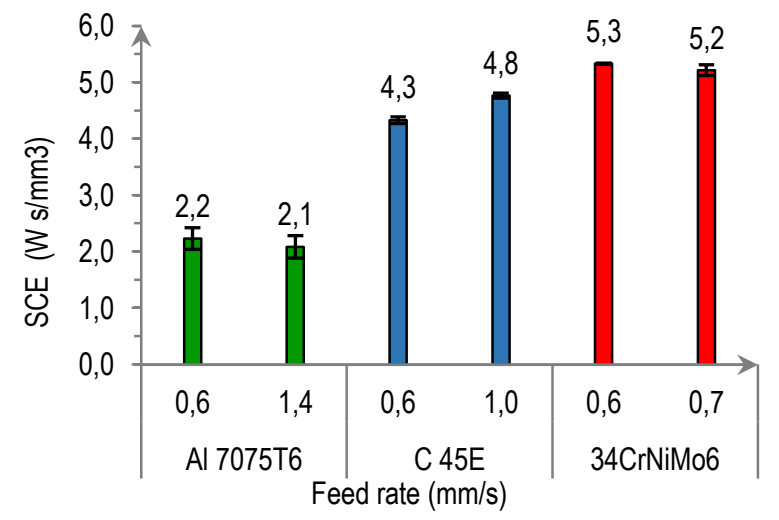

Fig. 6a. SCE depending on the material and the feed rate for a $V c=5.5 \mathrm{~m} / \mathrm{min}$.

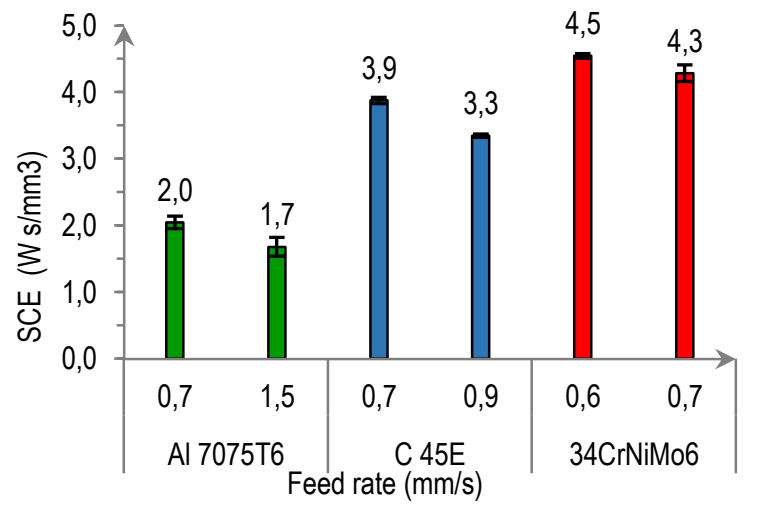

Fig. 6 . SCE depending on the material and the feed rate for a $V c=10 \mathrm{~m} / \mathrm{min}$.

For an average cutting speed of the drill of $5.5 \mathrm{~cm} / \mathrm{min}$, the SCE has a reverse behavior with the Va. In other words, higher the Va the lower is SCE, which implies that it is easier to break the material, a tendency that can be seen in the three materials during experiments. In a future work, the intention is to investigate the behavior of these materials even at higher cutting speeds in order to verify if this trend is maintained. On the other hand, Fig.6a and Fig. $6 \mathrm{~b}$ show that the SCE not only depends on the material to be machined, but also depends on the conditions of feed rate Va and the cutting speed Vc.

The methodology developed in this work allows to obtain SCE as a function of the active power and the material removal rate. This idea is generic and can be applied to any chip removal machine. The active power is a simple parameter to measure and can be applied to any electrical machine. The material removal rate depends on each chip removal process such as round turning, milling and drilling.

\begin{tabular}{|c|c|c|}
\hline & $\begin{array}{c}\text { Publicaciones DYNA SL }- \text { c) Mazarredo n69 - } 4^{0}-\text { 48009-BILBAO (SPAIN) } \\
\text { Tel }+34944237566 \text {-www.revistadyna.com - email: dyna@revistadyna.com }\end{array}$ \\
\hline
\end{tabular}




\begin{tabular}{|c|c|c|}
\hline $\begin{array}{l}\text { Ingeniería e Industria } \\
\text { Ind }\end{array}$ & MACHINABILITY ESTIMATION BY DRILLING MONITORING & $\begin{array}{r}\text { ELECTRICAL AND } \\
\text { MECHANICAL } \\
\text { ENGINEERING }\end{array}$ \\
\hline RESEARCH ARTICLE & Hernán A. González Rojas, Amelia Nápoles Alberro, Antonio J. Sánchez Egea & $\begin{array}{r}\text { Machine, tool, } \\
\text { accessories }\end{array}$ \\
\hline
\end{tabular}

The transfer of this methodology to the machine manufacturing sector begins by understanding that the model of the SCE is simple and can be used to find cutting conditions that prolong the life of the tools, reduce the cutting forces, improve surface finishes and the dimensional tolerances. Once the real potential of the model is understood, the cycle of the transfer will close showing how the modification and instrumentation of a conventional drilling can convert this device into an instrument for measuring the SCE. This work is a part of the global vision of the machining of high cost components, an aspect that requires intelligent manufacturing as a global process, which is in line with the industrial philosophy 4.0. In this philosophy, there is a tendency to virtualization and instrumentation of machine tools and processes, also called Virtual Twins. A fundamental part of the development of these twins is the integration of models that can offer information prior to the execution of machining. The SCE is a simple model capable of offering information that allows accurate planning of the chip removal process.

\section{4.- CONCLUSIONES}

The configured equipment allows a quick and reliable estimation of the SCE for its use in the planning and precise definition of the cutting conditions of a machining process. For this, it requires the measurement of the active power consumed by the machine and the feed rates of the drill. Both quantities are easy to measure and the measuring devices are of low cost.

A methodology has been developed successfully for evaluating SCE, depending on the active power consumed by the machine and the feed rates of drill. In this way, with the measurements of these parameters, it is only necessary to calculate the mechanical power, the cutting power and the material removal rate, whose expression changes shape depending on the process: turning, milling or drilling.

The method has been validated by studying the SCE of three materials of different constitution and hardness. It has been possible to verify that the estimated SCE coincides with the values measured by other authors and therefore this validates the method which is the main objective of this work. In addition, it has been possible to observe the dependence of the SCE on the feed rate and the cutting speed, highlighting the sensitivity shown by the developed method.

A lower SCE is associated with better machinability, lower cutting force, lower spindle speed and / or a higher material removal rate. The latter is associated with the cutting conditions and parameters that can be modified to lower the SCE, thus optimizing the process of chip removal, increasing the useful life of the tools and prolonging the life of the machines.

\section{BIBLIOGRAPHY}

[1] Merchant ME. An Interpretive Look at the 20th Century Research on Sciences and Engineering Modeling of Machining. Machining Science and Technology. 1998. Vol.2 p.157-163.

[2] Fernández-Abia Al, Barreiro J, López de Lacalle LN. Effect of very high cutting speeds on shearing, cutting forces and roughness in dry turning of austenitic stainless steels. International Journal of Advanced Manufacturing Technology. 2011. Vol.57 p.61-71. DOI http://dx.doi.org/10.1007/s00170-011-3267-9.

[3] Beranoagirre A, Olvera D, López de Lacalle LN. Milling of gamma titanium-aluminum alloys. International Journal of Advanced Manufacturing Technology. 2012. Vol.62 p.83-88. DOI http://dx.doi.org/10.1007/s00170-011-3812-6.

[4] King RI, Hahn RS. Handbook of Modern Grinding Technology. USA: Ed. Chapman and Hall, 1986. 360p. ISBN: 978-1-4613-1965-8.

[5] Biró I, Szalay T. Extension of empirical specific cutting force model for the process of fine chip-removing milling. The International Journal of Advanced Manufacturing Technology. 2017. Vol.88 p.2735-2743. DOI http://dx.doi.org/10.1007/s00170-016-8957-x.

[6] Rodrigues AR, Coelho RT. Influence of the tool edge geometry on specific cutting energy at high-speed cutting. Journal of the Brazilian Society of Mechanical Sciences and Engineering. 2007. Vol.XXIX-3 p.279-283.

[7] Xie J, Liu F, Qiu H. An integrated model for predicting the specific energy consumption of manufacturing processes. The International Journal of Advanced Manufacturing Technology. 2016. Vol.85 p.1339-1346. DOI http://dx.doi.org/10.1007/s00170-015-8033-y.

\begin{tabular}{|c|c|c|}
\hline & $\begin{array}{l}\text { Publicaciones DYNA SL -- c) Mazarredo n'69 - } 4^{\circ} \text { - } 48009 \text {-BILBAO (SPAIN) } \\
\text { Tel +34 } 944237566 \text { - www.revistadyna.com - email: dyna@revistadyna.com }\end{array}$ & Pag. $7 / 8$ \\
\hline
\end{tabular}




\begin{tabular}{|l|r|r|}
\hline \\
Ingeniería e Industria \\
RESEARCH ARTICLE
\end{tabular}

[8] Wu X, Li L, Zhao M, et al. Experimental investigation of specific cutting energy and surface quality based on negative effective rake angle in micro turning. The International Journal of Advanced Manufacturing Technology. 2016. Vol.82 p.1941-1947. DOI http://dx.doi.org/10.1007/s00170015-7548-6.

[9] Camposeco-Negrete C, Calderón-Nájera JD, Miranda-Valenzuela JC. Optimization of cutting parameters to minimize energy consumption during turning of AISI 1018 steel at constant material removal rate using robust design. The International Journal of Advanced Manufacturing Technology. 2016. Vol.83 p.1341-1347. DOI http://dx.doi.org/10.1007/s00170-015-7679-9.

[10] Sánchez-Egea AJ, González-Rojas HA, Montilla-Montaña CA, et al. Effect of electroplastic cutting on the manufacturing process and surface properties. Journal of Materials Processing Technology. 2015. Vol.222 p.327-334.

[11] Hameed S, González-Rojas HA, Sánchez-Egea AJ, et al. Electroplastic cutting influence on power consumption during drilling process. The International Journal of Advanced Manufacturing Technology. 2016. Vol.87 p.1835-1841. DOI http://dx.doi.org/10.1007/s00170-016-8562-z.

[12] Urbikain G, López de Lacalle L.N, Campa F.J, Fernández A, Elías A. Stability prediction in straight turning of a flexible workpiece by collocation method. International Journal of Machine Tools \& Manufacture. 2012. Vol.54-55 p.73-81. Doi: http://dx.doi.org/10.1016/i.ijmachtools.2011.11.008.

[13] V.D. Coronel Asistiri, Estudio de la maquinabilidad de algunos materiales utilizados en la indústria, Bachelor thesis, http://hdl.handle.net/2117/112641

[14] Kalpakjian S, Schmid SR. Manufactura, Ingeniería y Tecnología, Prentice Hall, 2009. 1328p. ISBN: 978-9-7026-1026-7.

[15] Saqib Hameed, Hernán A. González Rojas, José I. Perat Benavides, Amelia Nápoles Alberro and Antonio J. Sánchez Egea (2018). Influence of the Regime of Electropulsing-Assisted Machining on the Plastic Deformation of the Layer Being Cut. Materials, 11, 886: 1-12; doi: http://dx.doi.org/10.3390/ma11060886

\section{ACKNOWLEDGMENTS}

This work was carried out with the support of the Ministry of Economy and Competitiveness of Spain (project reference: FJCI-2016-29297) and the Chilean National Commission for Scientific and Technological Research CONICYT (Fondecyt project 3180006). In addition, the collaboration of the student of Mechanical Engineering Vanessa Daniela Coronel Asistiri, in the realization of the experimental measurements of the specific energy and the statistical treatment of the information is appreciated, since the measurement of the SCE needs the attention of two people.

\begin{tabular}{|c|c|c|}
\hline & $\begin{array}{c}\text { Publicaciones DYNA SL -- c) Mazarredo no69 - } 4^{\circ}-48009 \text {-BILBAO (SPAIN) } \\
\text { Tel +34 } 944237566 \text { - www.revistadyna.com - email: dyna@revistadyna.com }\end{array}$ & Pag. 8 / 8 \\
\hline
\end{tabular}

